\title{
H2BC7 Gene
}

National Cancer Institute

\section{Source}

National Cancer Institute. H2BC7 Gene. NCI Thesaurus. Code C162928.

This gene is involved in histone-mediated DNA compaction. 